American Journal of Pharmaceutical Education 2019; 83 (10) Article 7367.

\title{
RESEARCH
}

\section{An Analysis of Canadian Doctor of Pharmacy Student Experiences in Non- Traditional Student-Preceptor Models}

\author{
Caitlin McIntyre, PharmD, ${ }^{\mathrm{a}}$ Cindy Natsheh, PharmD, ${ }^{\mathrm{b}, \mathrm{c}}$ Kori Leblanc, PharmD, ${ }^{\mathrm{b}, \mathrm{c}}$ \\ Olavo Fernandes, PharmD, ${ }^{\text {b,c }}$ Aleksandra Bjelajac Mejia, PharmD, ${ }^{\mathrm{c}}$ Lalitha Raman-Wilms, PharmD, ${ }^{\mathrm{c}, \mathrm{d}}$ \\ Karen Cameron, BScPharm ${ }^{\text {,c }}$ \\ ${ }^{\text {a }}$ Hôpital Montfort, Ottawa, Ontario, Canada \\ ${ }^{\mathrm{b}}$ University Health Network, Toronto, Ontario, Canada \\ ${ }^{\mathrm{c}}$ University of Toronto, Leslie Dan Faculty of Pharmacy, Toronto, Ontario, Canada \\ ${ }^{\mathrm{d}}$ University of Manitoba, College of Pharmacy, Winnipeg, Manitoba, Canada \\ Submitted September 5, 2018; accepted May 22, 2019; published December 2019.
}

\begin{abstract}
Objective. To describe students' experiences and perceptions of non-traditional student-preceptor learning models and evaluate the effectiveness of these models on students' learning experience.

Methods. Pharmacy students who had completed at least one experiential rotation with a nontraditional learning model participated in semi-structured interviews. Models included peer-assisted learning (PAL; two or more students of same educational level), near-peer teaching (NPT; one or more junior students with one or more senior students), and co-preceptorship (CoP; two or more preceptors). Interviews were transcribed, coded, and analyzed for themes. Themes were mapped according to the Kirkpatrick model for evaluating educational training.

Results. Twenty semi-structured interviews were conducted. Forty-three experiences (19 CoP, 14 PAL, 10 NPT) from 14 institutions were described. Many themes overlapped between the three models. In CoP, learners described increased preceptor availability and exposure to different patient care approaches. Challenges arose when preceptors had different expectations. Students overwhelmingly endorsed a multi-learner environment. Both PAL and NPT learners felt supported as collaboration with other learners was readily fostered. Potential challenges in PAL and NPT were difficulties when personalities conflicted and when there was a significant knowledge gap between the learners. All three models allowed for the development of skills, including communication and collaboration. Learners reported an enhanced approach to patient care and professional practice, including approaches to teaching as new preceptors.
\end{abstract}

Conclusion. Pharmacy students and graduates valued their experiences in non-traditional studentpreceptor models. Institutions may find support for using these precepting models to increase placement capacity.

Keywords: experiential education, preceptor models, pharmacy student, peer education, PharmD

\section{Introduction}

In recent years, the expected level of performance for Canadian pharmacy graduates has increased because of the continued expanded scope of practice in Canada and a shift to the Doctor of Pharmacy (PharmD) degree as the entry-to-practice degree. ${ }^{1,2}$ One major adjustment has been related to experiential education requirements. Experiential education provides pharmacy students the

Corresponding Author: Caitlin McIntyre, Hôpital Montfort, 713 Montreal Rd., Ottawa, ON K1K 0T2, Canada. Tel: 613746-4621 ext. 6820. Fax: 613-907-8026. Email:

caitlinmcintyre@montfort.on.ca. opportunity to apply knowledge and skills learned in courses and in simulated settings in practice. ${ }^{1}$ Institutions are now required to provide a greater number of experiential rotations for longer duration to support the requirements for PharmD programs. ${ }^{1,2}$ For instance, at a large academic teaching hospital in Toronto, Canada, the total number of experiential rotations offered to learners increased from 57 before the entry-to-practice PharmD (2011-2012) to 197 rotations (2015-2016). ${ }^{3}$

Institutions in the United States, where the PharmD curriculum has been in place for many years, are also concerned over experiential education requirements as the number of pharmacy schools and student enrollment 


\section{American Journal of Pharmaceutical Education 2019; 83 (10) Article 7367.}

have increased in recent years. ${ }^{4}$ Providing clinical placements for a larger number of students has become increasingly challenging for institutions, as most rotations employ the traditional one-to-one student-preceptor model. ${ }^{3,5}$ This increase in demand has led pharmacy institutions to explore more non-traditional experiential teaching models. ${ }^{3,6}$

The most well-defined non-traditional student-preceptor models are peer-assisted learning (PAL), near-peer teaching (NPT), and co-preceptorships (CoP). ${ }^{6,7}$ Peerassisted learning is defined as two or more students at the same education level who are assigned to one or more of the same preceptors. ${ }^{5,6,8}$ In contrast to PAL, NPT (also known as layered learning, hierarchical model, pyramidal teaching) is defined as one or more senior learners and one or more junior learners assigned to one or more of the same preceptors. ${ }^{5,6,9,10}$ Finally, CoP is defined as more than one preceptor assigned to a student or group of students. ${ }^{5,6}$

Non-traditional teaching models, including PAL, NPT, and CoP, have been used successfully by other professions, including nursing, medicine, and physical therapy. ${ }^{5,11-14}$ In pharmacy education, most of the evidence evaluating non-traditional teaching models is from the United States, however much of the focus there has been on evaluating clinical indicators (ie, number of medication histories, patient education sessions, and medication-related problems identified), and few have studied student perceptions of the learning experience. ${ }^{15-}$ ${ }^{22}$ Because these models are yet to be used widely within Canadian pharmacy education, they are less well described in the Canadian context. Some Canadian institutions have reported positive benefits for both students and preceptors with the use of PAL, NPT, and CoP in pharmacy education. ${ }^{6,8-10}$ Given the limited experience with these models in Canadian pharmacy education programs and the limited evidence looking at student perceptions internationally, we decided to specifically explore the student experience in these models. We used a qualitative research approach with semi-structured interviews to obtain rich descriptions to better characterize students' perceptions of and outcomes from these non-traditional teaching models.

\section{Methods}

Students from three graduating classes $(2015,2016$, 2017) of the entry-to-practice PharmD program at the Leslie Dan Faculty of Pharmacy, University of Toronto, who were assigned to affiliated teaching institutions for their final-year experiential rotations were invited to participate in this study. Of the 10 pharmacy schools in Canada, the University of Toronto was the largest, with a class size of 240 students. There were 43 weeks of experiential education in the program, with the majority of the rotations taking place in the fourth year of the program (35 weeks). Although the majority of students chose to do their rotations locally in Toronto, students had the option of going anywhere in Canada. The study protocol was approved by the institution's research ethics board.

Learners were invited via email to participate in a semi-structured interview to describe their experiences in non-traditional teaching models. The purposeful sampling technique was used to select participants from different graduating classes who could speak to their experience with one or more of the non-traditional student-preceptor models. ${ }^{23}$ All participants had experienced at least one traditional rotation with a one-to-one student-preceptor model. According to the school's 20152017 experiential rotation database, approximately 175 students completed a co-preceptorship rotation $(n=248$ rotations) and 139 students completed a peer-assisted learning rotation ( $\mathrm{n}=179$ rotations). However, this database may not have captured all student-preceptor models. For instance, two preceptors who were each assigned a student and worked in the same unit may have chosen to combine their rotations and precept the students together. Additionally, students from other pharmacy schools who were assigned the same preceptor were not captured in this database. Furthermore, the denominator for near-peer teaching rotations is not known as senior learners, such as pharmacy residents or students from other institutions, were not recorded in this particular university database.

One-on-one semi-structured interviews were conducted either by phone or in person in a private area with no interruptions. Written informed consent was obtained from students prior to starting the interview. Interviews ranged from 20 to 54 minutes and were conducted by one of the authors, who was a pharmacy resident at the time of the study and not involved in the evaluation of any of these students during their rotations. To maintain an unbiased and nonthreatening environment, neither faculty members nor preceptors were present during the interviews. The interviewer followed an interview guide that was based on the amended version of Kirkpatrick's hierarchy, a version of the tool that had been used to evaluate medical training education programs. ${ }^{24,25}$ The amended version of Kirkpatrick's levels included perception of training by the subject; change in the subject's attitudes and change in the subject's knowledge and/or skills; change in the subject's behavior, and change in the subject's professional practice. ${ }^{25}$ The interview guide was pilot tested with two learners, revised, and retested prior to data collection. Open-ended questions were asked 


\section{American Journal of Pharmaceutical Education 2019; 83 (10) Article 7367.}

using a conversational dialogue to allow the participant to respond in their own words. We recognized the possibility for social desirability bias to occur, which is when participants give what they think is the preferred social response rather than giving their "true" answer. ${ }^{26} \mathrm{We}$ believed this might occur when students were discussing rotations in which they failed or did poorly. In these cases, the interviewer reminded participants that responses were confidential and there were no correct answers. The interviewer could also reframe questions or use hypothetical cases in order to elicit more personal responses. For example, reframing questions regarding evaluations or preceptor interactions, or discussing hypothetical situations between preceptors and learners helped to elicit truthful responses.

All interviews were digitally recorded and transcribed. Thematic analysis of the interview transcripts was an iterative process that involved coding of the text, grouping of codes into categories, and theme generation based on the content of each category. In order to decrease the potential for any undue bias, six transcripts were initially coded by four independent reviewers. Codes were then discussed and reviewed in collaboration to ensure credibility and consistency of the coding and develop a codebook. Two investigators coded all remaining transcripts. After coding was complete, consensus discussions were held with the other investigators to identify categories and themes according to conventional content analysis. $^{27}$

An amended version of Kirkpatrick's levels for appraising educational interventions was used as an analytical framework to evaluate the three models. ${ }^{24}$ While this version has been used in medical education contexts, it has also been critiqued for being too rigid in its evaluation. ${ }^{28}$ For instance, it does not take into account the "teacher's role" and may not allow for evaluation of all outcomes that may be involved in complex interventions. ${ }^{28}$ In order to minimize these limitations, we specifically asked students about their interactions with their preceptor(s) using open-ended questions to elicit rich descriptions of experiences. Additionally, during the analysis, an openness was maintained while analyzing the codes so that additional categories could be identified if present. The constant comparison technique was used in order to increase the validity of the data. This technique allowed us to compare and consider the interviews of all participants, rather than individual interviews, in order to identify unanticipated themes. ${ }^{29}$ NVivo 11 (QSR International, Cambridge, MA) was used for all transcript analysis. A member external to the project team with significant experience with qualitative study was involved in the validation of the codes and categories.

\section{Results}

Twenty semi-structured interviews were undertaken between March and May 2017. Participants and their rotations are illustrated in Table 1 . The majority of nontraditional rotations were experienced in an ambulatory setting. All experiential rotations took place within the three years prior to the interview. Approximately $11 \%$ (19/175) of students who experienced co-preceptorships volunteered to participate, and 10\% (14/139) of students who experienced peer-assisted learning participated. The proportion of students who participated in near-peer teaching is not known for reasons previously discussed. After conducting approximately 10 interviews for each model, saturation was achieved as no additional perspectives on the non-traditional teaching models were reported by participants. However, we did not reach data saturation for learners in a senior role in NPT as there was only one participant who had experienced this role.

Table 1. Characteristics of Doctor of Pharmacy Students and Experiential Education Sites Included in an Analysis of Nontraditional Student-Preceptor Models

\begin{tabular}{|c|c|}
\hline Characteristic & No. \\
\hline \multicolumn{2}{|l|}{ 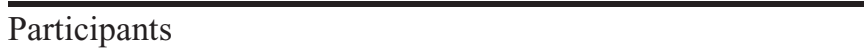 } \\
\hline \multicolumn{2}{|l|}{ Graduation Year $(n=20)$} \\
\hline 2017 & 10 \\
\hline 2016 & 5 \\
\hline 2015 & 5 \\
\hline \multicolumn{2}{|c|}{ Interview communication mode $(n=20)$} \\
\hline In-person & 9 \\
\hline Telephone & 11 \\
\hline \multicolumn{2}{|c|}{ Non-traditional Teaching $\operatorname{Model}^{\mathrm{a}}(\mathrm{n}=20)$} \\
\hline $\mathrm{CoP}$ & 19 \\
\hline PAL & 14 \\
\hline NPT & 10 \\
\hline \multicolumn{2}{|l|}{ Experiential Education Site } \\
\hline Institution Type $(\mathrm{n}=14$ sites & \\
\hline Teaching hospital & 10 \\
\hline Non-teaching hospital & 4 \\
\hline \multicolumn{2}{|l|}{ Rotation type $(\mathrm{n}=43$ rotations $)$} \\
\hline Ambulatory & 10 \\
\hline Antimicrobial Stewardship & 2 \\
\hline Critical Care & 5 \\
\hline General Medicine & 5 \\
\hline Multiple units & 6 \\
\hline Pediatrics & 3 \\
\hline Project/Research & 4 \\
\hline Psychiatry & 2 \\
\hline Surgery & 6 \\
\hline
\end{tabular}




\section{American Journal of Pharmaceutical Education 2019; 83 (10) Article 7367.}

Table 2. Summary of Kirkpatrick's Level 1, Perceptions of the Learning Experience, and Corresponding Themes and Examples Reported by Canadian Doctor of Pharmacy Students Who Completed a Rotation in Which a Non-Traditional Student-Preceptor Model Was in Place

\begin{tabular}{|c|c|c|}
\hline Level & Themes & Examples \\
\hline \multirow[t]{2}{*}{$\begin{array}{l}\text { Level 1: Perceptions of the } \\
\text { Learning Experience (CoP) }\end{array}$} & $\begin{array}{l}\text { Enjoyed rotation, increased preceptor } \\
\text { availability, more feedback, exposure to } \\
\text { different patient care approaches, } \\
\text { different teaching styles }\end{array}$ & $\begin{array}{l}\text { "It's kind of like a two-for-one deal. Like you } \\
\text { get to have twice as much input. So you only } \\
\text { have a few direct clinical rotations where you } \\
\text { get to see some of the thought process kind of } \\
\text { unwind and learn from that, so with that } \\
\text { model I got to see and learn that from two } \\
\text { preceptors rather than one." }\end{array}$ \\
\hline & $\begin{array}{l}\text { Challenges: different expectations, lack of } \\
\text { communication between preceptors, } \\
\text { disjointed evaluation }\end{array}$ & $\begin{array}{l}\text { "One preceptor expects one thing, and then } \\
\text { you're trying to work towards that but then } \\
\text { when you switch to the other preceptor, and } \\
\text { they expect something else and it's kind of a } \\
\text { disconnect there..." }\end{array}$ \\
\hline \multirow[t]{2}{*}{$\begin{array}{l}\text { Level 1: Perceptions of the } \\
\text { Learning Experience (PAL) }\end{array}$} & $\begin{array}{l}\text { Enjoyable experience, peer companionship, } \\
\text { mentorship, less individualized pressure, } \\
\text { collaborative patient care ('bounce ideas } \\
\text { off each other"), friendly competition }\end{array}$ & $\begin{array}{l}\text { "All throughout pharmacy school, you go to } \\
\text { lecture with } 200 \text { other people, and you study } \\
\text { with a group of friends. And then you're } \\
\text { dumped into your APPE rotation and all of a } \\
\text { sudden, you're there, all alone, and all the } \\
\text { tension is on you. That can be very jarring. } \\
\text { I've always learned well in groups. I've } \\
\text { always studied with at least } 1 \text { other person. } \\
\text { And for me personally it suited my learning } \\
\text { style really well. I think that it was just, there } \\
\text { was just a level of comfort and ease of having } \\
\text { another student with me." }\end{array}$ \\
\hline & $\begin{array}{l}\text { Challenges: knowledge gap between the } \\
\text { students, conflicting personalities, } \\
\text { (theoretical) competition }\end{array}$ & $\begin{array}{l}\text { "When the other student was able to... was } \\
\text { granted permission to round independently } \\
\text { whereas I wasn't. . . that kind of prompted me } \\
\text { to step-up my game and take on more } \\
\text { responsibility to get that." }\end{array}$ \\
\hline & $\begin{array}{l}\text { Challenges: junior learners felt } \\
\text { intimidated, (theoretical) competition }\end{array}$ & $\begin{array}{l}\text { "It was actually nice to just have less attention } \\
\text { on you all the time... and just have it } \\
\text { distributed... like the attention was on } \\
\text { someone else every once in a while, } \\
\text { especially when you're not having a good } \\
\text { day." }\end{array}$ \\
\hline
\end{tabular}

Abbreviations: $\mathrm{APPE}=$ advanced pharmacy practice experience, $\mathrm{CoP}=$ co-preceptorship, $\mathrm{PAL}=$ peer-assisted learning, $\mathrm{NPT}=$ near-peer teaching

Nevertheless, we reached data saturation for the NPT junior learner role. The major themes for each teaching model were organized using Kirkpatrick's levels (Tables 2-6).

Perceptions of the learning experiences were organized under level 1 of Kirkpatrick's hierarchy. Most students recalled enjoyable experiences. In the $\mathrm{CoP}$ model, students described the benefits of increased preceptor availability, feedback, and exposure to different patient care approaches. Students felt they were able to identify their strengths and areas for improvement better from receiving feedback from multiple sources.

Many students in PAL preferred to have peer companionship on rotations because they felt more supported and less individualized pressure. This type of peer-to-peer relationship allowed for collaborative patient care, where 


\section{American Journal of Pharmaceutical Education 2019; 83 (10) Article 7367.}

Table 3. Summary of Kirkpatrick's Level 2a, Change in Attitudes, and Corresponding Themes and Examples Reported by Canadian Doctor of Pharmacy Students Who Completed a Rotation in Which a Non-Traditional Student-Preceptor Model Was in Place

\begin{tabular}{|c|c|c|}
\hline Level & Themes & Examples \\
\hline $\begin{array}{l}\text { Level 2a: Change in } \\
\text { Attitudes (CoP) }\end{array}$ & $\begin{array}{l}\text { Different approaches to solving } \\
\text { complex drug therapy problems } \\
\text { Value of teamwork and } \\
\text { working collaboratively }\end{array}$ & $\begin{array}{l}\text { "I could kind of learn about what style of } \\
\text { pharmacist they were and what they thought } \\
\text { about and what their opinions were. Most of } \\
\text { the time they were the same, but every now } \\
\text { and then there was some controversy too... } \\
\text { they might have different opinions and they } \\
\text { would both have great arguments for them." } \\
\text { "Having two people doing the same job, it's } \\
\text { important because it shows you the value of } \\
\text { teamwork and that's something that is very } \\
\text { important in health care systems." }\end{array}$ \\
\hline $\begin{array}{l}\text { Level 2a: Change in } \\
\text { Attitudes (PAL) }\end{array}$ & $\begin{array}{l}\text { Benchmark progress, validate concerns/ } \\
\text { challenges, decreased learner anxiety }\end{array}$ & $\begin{array}{l}\text { "If I was struggling, I could look to the other } \\
\text { student and say ok - she's also struggling so } \\
\text { maybe what I'm experiencing is normal... } \\
\text { whereas in the [traditional model] I had no } \\
\text { idea if I was just a really slow learner, or if the } \\
\text { rotation was just really hard." }\end{array}$ \\
\hline $\begin{array}{l}\text { Level 2a: Change in } \\
\text { Attitudes (NPT) }\end{array}$ & $\begin{array}{l}\text { Increased motivation, shared workload } \\
\text { responsibility, decreased learner anxiety }\end{array}$ & $\begin{array}{l}\text { "It was really eye-opening ... it's one thing } \\
\text { when they tell you how to do things, but when } \\
\text { you see another student actually doing it, and } \\
\text { doing it very well. . It was really... } \\
\text { especially for instance how she would } \\
\text { approach the patient, talk to them, handle a } \\
\text { situation, that was very valuable to me } \\
\text { because I got. . . it gave me confidence to just } \\
\text { go ahead and take charge of that patient (...) } \\
\text { I think it would've been different if she } \\
\text { wasn't there. ..it would have probably been } \\
\text { based on the preceptor feedback, which may } \\
\text { or may not have been helpful compared to } \\
\text { visually seeing someone." }\end{array}$ \\
\hline
\end{tabular}

Abbreviations: $\mathrm{CoP}=$ co-preceptorship, $\mathrm{PAL}=$ peer-assisted learning, $\mathrm{NPT}=$ near-peer teaching

students relied on each other to problem solve before consulting their preceptor. Several students described that this relationship was facilitated if students had their workspaces close to each other. Although students said they felt more comfortable asking questions of each other first, they recognized that they were not experts and ultimately needed to confer with the preceptor.

Similarly, in NPT, there were many opportunities for collaborative learning and learners reported they enjoyed the companionship. Students felt their learning environment was supportive as they had someone with whom they felt comfortable asking questions. Again, they reiterated that workspace proximity allowed for more opportunities to ask questions and discuss issues. There were some challenges with these models that are important to describe. Although many learners in the PAL and NPT models raised the perception of peer competition as a concern, some learners said this friendly competition motivated them. No one we interviewed reported having a negative experience with competition during their rotation. This may have been because of the clear differences in expectations of the more senior learner compared with those of the more junior learner. Another potential concern was less individual preceptor attention, which could make it difficult to identify each learners' weaknesses. However, several learners liked having less preceptor attention as this decreased learner anxiety. Several participants stated that significant knowledge gaps and conflicting personalities made it more difficult for collaborative learning to occur when several learners were together. In CoP, problems sometimes arose when there was a lack of communication between the preceptors, 


\section{American Journal of Pharmaceutical Education 2019; 83 (10) Article 7367.}

Table 4. Summary of Kirkpatrick's Level 2b, Change in Knowledge and Skills, and Corresponding Themes and Examples Reported by Canadian Doctor of Pharmacy Students Who Completed a Rotation in Which a Non-Traditional Student-Preceptor Model Was in Place

\begin{tabular}{lc}
\hline Level & Themes \\
\hline Level 2b: Change in & In-depth therapeutic discussions, \\
Knowledge and Skills (CoP) & communication, collaboration and \\
& teamwork, adaptation (different \\
& teaching styles, expectations)
\end{tabular}

Level 2b: Change in Knowledge and Skills (PAL)

Level 2b: Change in Knowledge and Skills (NPT)
Helped overall learning experience, increased exposure to patient cases, peer mentorship, teaching, self-directed practice, responsibility, teamwork and collaboration, communication
Increased learning, mentorship, teaching, self-management, communication, collaboration and teamwork, more exposure to patient cases

\section{Examples}

"It just forced me to learn how to navigate the relationship with two different people with two different preceptors. So every preceptor is different, every boss is going to be different, and so we have to learn how to adapt and work within those different personalities and different expectations."

"When I had multiple preceptors, they would specifically schedule my therapeutic talks to make sure the person who wrote the guidelines for it or was an expert on it was the one teaching me the topic so I think I got the most out of it by having that experience."

"I feel like if I can 'teach it' or guide them to, or orienting them to the processes or inpatient care process - that helped to strengthen my knowledge as well."

"Teamwork played a huge part of that rotation, especially because there are a lot of patients and if it was just one student it would not be possible... so we divide all the patients among us, so it was nice having the two other PharmD students there. It also provided a nice valuable resource for learning as well, we can kind of always help each other out on all of the patients."

"[Senior learners] had really good intuitive discussion during the meetings... good communication skills when they were posing questions or during their presentations that I learned from."

"We were able to discuss our patient cases and what we thought. And oftentimes that would lead to kind of like just therapeutic topics ... for example, our patient might have had insomnia and they tried $\mathrm{X}$ and $\mathrm{Y}$. What is another alternative? And what are the advantages and disadvantages?"

Abbreviations: $\mathrm{CoP}=$ co-preceptorship, $\mathrm{PAL}=$ peer-assisted learning, $\mathrm{NPT}=$ near-peer teaching

specifically around a student's progress. Students reported having to retell experiences to the other preceptor(s) during evaluation to justify their achievements, which was frustrating. This was especially true if one preceptor had spent more time with the student than the other and had been able to observe their progress more closely throughout the rotation.

For level 2a of Kirkpatrick's levels we described changes in attitudes. Students identified many benefits of the non-traditional teaching models. The CoP environments enabled students to observe different preceptors' approaches to solving complex drug therapy problems. Students also gained valuable insight into the importance in working collaboratively to provide patient care, which they describe being able to apply to their future practice. Students in PAL rotations appreciated the opportunities to benchmark their progress and validate their concerns if they were finding a specific aspect of the rotation challenging. This resulted in decreased learner anxiety. Junior learners valued being able to observe 


\section{American Journal of Pharmaceutical Education 2019; 83 (10) Article 7367.}

Table 5. Summary of Kirkpatrick's Level 3, Changes in Behavior, and Corresponding Themes and Examples Reported by Canadian Doctor of Pharmacy Students Who Completed a Rotation in Which a Non-Traditional Student-Preceptor Model Was in Place

\begin{tabular}{|c|c|c|}
\hline Level & Themes & Examples \\
\hline $\begin{array}{l}\text { Level 3: Changes in Behavior } \\
\text { (Approach to Patient Care) } \\
\text { (CoP) }\end{array}$ & $\begin{array}{l}\text { Improved patient care workup, } \\
\text { patient presentations, patient } \\
\text { education framework }\end{array}$ & $\begin{array}{l}\text { "I got feedback from two different pharmacists } \\
\text { in terms of patient work-up... it's like having } \\
\text { a second eye also looking at your work and } \\
\text { how you can improve. So combining both } \\
\text { feedback and applying to your work - I } \\
\text { definitely saw an improvement in my patient } \\
\text { care work up in my subsequent institutional } \\
\text { rotations." }\end{array}$ \\
\hline $\begin{array}{l}\text { Level 3: Changes in Behavior } \\
\text { (Approach to Patient Care) } \\
\text { (PAL) }\end{array}$ & $\begin{array}{l}\text { Improved studying habits and } \\
\text { information organization, } \\
\text { developed patient care work-up } \\
\text { and presentation style, exposure } \\
\text { to pharmacy resources, enhanced } \\
\text { therapeutic thought process }\end{array}$ & $\begin{array}{l}\text { "Seeing how they would present and then just } \\
\text { really liking something that they did and then } \\
\text { saying - oh I can incorporate that in [my care } \\
\text { plan] too." } \\
\text { "There was a big learning curve just from the } \\
\text { fact that it was my first institutional rotation. } \\
\text { And I got to observe the other student and } \\
\text { how she approached patient cases and } \\
\text { incorporate some of her approach into my } \\
\text { own. I saw how organized her notes were and } \\
\text { how good she was at tracking information } \\
\text { about patients over time, and that was } \\
\text { something that I tried to adopt as well, } \\
\text { because I saw how helpful it was." }\end{array}$ \\
\hline $\begin{array}{l}\text { Level 3: Changes in Behavior } \\
\text { (Approach to Patient Care) } \\
\text { (NPT) }\end{array}$ & $\begin{array}{l}\text { Improved patient care work-up } \\
\text { and presentation style, } \\
\text { interprofessional communication, } \\
\text { exposure to pharmacy resources, } \\
\text { enhanced therapeutic thought process }\end{array}$ & $\begin{array}{l}\text { "I would review my patients with (the pharmacy } \\
\text { resident) and they were really helpful because } \\
\text { they were able to ask questions that I didn't } \\
\text { consider. They would teach me where their } \\
\text { thought process was coming from and the key } \\
\text { things that they had gained from other } \\
\text { rotations. .I feel like the preceptors had all } \\
\text { those thought processes internalized versus } \\
\text { for the residents they had all these new tips } \\
\text { and things to consider that they had just } \\
\text { learned throughout that year and they were } \\
\text { able to explain that a lot more." }\end{array}$ \\
\hline
\end{tabular}

Abbreviations: $\mathrm{CoP}=$ co-preceptorship, $\mathrm{PAL}=$ peer-assisted learning, $\mathrm{NPT}=$ near-peer teaching

senior learners on rotation in NPT models. This increased their motivation to attain a similar level of knowledge and skill.

For Kirkpatrick's level 2b, we described students' reported changes in knowledge and skills. Overall, learners recognized improvements in their patient care skills and knowledge base. In CoP, students recalled several advantages from learning with two preceptors who had different areas of expertise. More in-depth therapeutic discussions were possible as the preceptor who had expertise in a specific clinical area could lead the discussion. The majority of students identified developing communication and teamwork skills; however, adaptation and collaboration were also mentioned frequently. Communication skills were particularly heightened when students acted as the link between the preceptors. Collaboration and teamwork skills resulted from working with more than one pharmacist and observing the preceptors working together.

Similarly, PAL increased knowledge acquisition as peer-to-peer teaching was abundant. When a subject area was challenging to one student, a peer was available to help translate into more relatable terms. This type of interaction also helped the peer-teacher to develop teaching skills. Additionally, PAL encouraged the development of a self-directed practice. Although at the beginning of the 


\section{American Journal of Pharmaceutical Education 2019; 83 (10) Article 7367.}

Table 6. Summary of Kirkpatrick's Level 4, Change in Professional Practice, and Corresponding Themes and Examples Reported by Canadian Doctor of Pharmacy Students Who Completed a Rotation in Which a Non-Traditional Student-Preceptor Model Was in Place

\begin{tabular}{|c|c|c|}
\hline Level & Themes & Examples \\
\hline \multirow[t]{2}{*}{$\begin{array}{l}\text { Level 4: Change in } \\
\text { Professional Practice (CoP) }\end{array}$} & $\begin{array}{l}\text { Adapting to different personalities } \\
\text { and expectations, personalized } \\
\text { professional practice framework }\end{array}$ & $\begin{array}{l}\text { "I got four different bosses providing different } \\
\text { types of feedback... so still kind of taking } \\
\text { that and integrating into my practice as well, } \\
\text { and being able to take feedback from } \\
\text { different people that present it differently." }\end{array}$ \\
\hline & $\begin{array}{l}\text { Establish clear expectations } \\
\text { for learners }\end{array}$ & $\begin{array}{l}\text { "I know that not every personality is like mine, } \\
\text { so I try to gauge what the other person's } \\
\text { personality is. . .like the student's personality } \\
\text { before... try to set those expectations, and } \\
\text { how they like to take feedback... What they } \\
\text { expect their pace should be and what I expect } \\
\text { their pace should be." }\end{array}$ \\
\hline $\begin{array}{l}\text { Level 4: Change in } \\
\text { Professional Practice (PAL) }\end{array}$ & $\begin{array}{l}\text { Embrace a collaborative } \\
\text { practice, peer teaching }\end{array}$ & $\begin{array}{l}\text { "We have pharmacists overlap for a couple } \\
\text { hours a day, so that's kind of like peer-to-peer } \\
\text { learning, even as pharmacists we are still } \\
\text { learning things, we still ask each other } \\
\text { questions." }\end{array}$ \\
\hline $\begin{array}{l}\text { Level 4: Change in } \\
\quad \text { Professional Practice (NPT) }\end{array}$ & $\begin{array}{l}\text { Value of collaboration and } \\
\text { teamwork, model behavior } \\
\text { for students }\end{array}$ & $\begin{array}{l}\text { ". .one of the main things were just really } \\
\text { learning to work on a team with everyone. } \\
\text { Learning the skills of cooperation because it } \\
\text { is something that is really important moving } \\
\text { forward into future career paths - it is a very } \\
\text { important skill to have learning to work with } \\
\text { someone on a team." } \\
\text { "I try to lead by example because I know that } \\
\text { (the students) are observing and they are } \\
\text { looking, just like I was looking at the other } \\
\text { student. So I know that. . I know that they } \\
\text { are seeing everything, hearing everything, so } \\
\text { I try as much as possible to model how things } \\
\text { should be properly done so that they know the } \\
\text { expectations that are expected of them." }\end{array}$ \\
\hline
\end{tabular}

Abbreviations: $\mathrm{CoP}=$ co-preceptorship, $\mathrm{PAL}=$ peer-assisted learning, $\mathrm{NPT}=$ near-peer teaching

rotation it may have felt as though there was a lack of preceptor availability, students reported that this allowed them to develop a sense of responsibility and teamwork skills, and to seek out other resources to answer their questions first before asking their preceptor. Collaboration and communication skills were further promoted when students brought different experiences from other PharmD rotations and pooled their resources. If the rotation had a staggered start, where one student had already been on the service, the more experienced student oriented the new student to the patient population, and the preceptor's expectations. This provided an easier transition for the new student and allowed the more experienced student to develop mentorship skills. Even if the rotation did not have a staggered start, students with more clinical experience expressed being able to mentor their peers. In NPT and PAL, learners quickly developed self-management skills as they talked about splitting the workload, discussed patients and clinical controversies together during their collaboration. In these interactions, the senior learner was able to share their past experiences and ask more complex practice-related questions. However, some of these discussions may have been too complex for the junior learners in NPT and some may have felt intimidated to contribute to the discussion.

Changes in behavior were organized in level 3 of Kirkpatrick's hierarchy. Learners endorsed positive changes in their approach to patient care as a result of their experiences in non-traditional teaching models. The CoP model enabled students to observe the similarities and 


\section{American Journal of Pharmaceutical Education 2019; 83 (10) Article 7367.}

differences in their preceptors' patient care approaches, allowing them to explore different strategies to identify drug therapy issues, educate patients, and provide recommendations to the care team. Additionally, more fulsome preceptor feedback on the student's patient care approach enriched the learning, especially if both preceptors were present during the student's patient presentations and evaluations. However, problems arose when expectations were different between the preceptors. In both PAL and NPT models, the opportunity to directly observe another learner's patient care skills, whether peer or senior learner, was highly valued. Through these exposures, learners had many opportunities to broaden their approaches to organizing information, presenting patient cases, formulating care plans, educating patients and making recommendations to the team. Additionally, there was more exposure to diverse patient cases which can broaden knowledge base and knowledge regarding different pharmacy resources. Unique to NPT models was the mentorship between the senior and junior learners. In this relationship, the senior learner helped review care plans, taught their thought process, and provided feedback during patient presentations. The senior learner acted as a bridge between classroom knowledge and hospital pharmacy practice, which was viewed as being very beneficial.

In Kirkpatrick's level 4, we described changes in professional practice. Many participants who were practicing pharmacists by the time of the interview recalled how their experiences in these models impacted their professional practices and role as new preceptors. In $\mathrm{CoP}$, exposure to different pharmacy practices and learning from more than one preceptor gave them insight into different backgrounds and career paths and allowed learners to develop their own personalized practice framework. In PAL and NPT, students readily embraced a collaborative practice and identified the value of being able to have discussions with their colleagues when dealing with complicated patient cases. When they were subsequently given the opportunity to be a preceptor, they attempted to model patient interactions because they remembered observing the behavior of the other learners for guidance on how to practice. Many felt comfortable incorporating the CoP model into their practice right away, and, notably, because of experiencing learning in this model, they understood the importance of establishing clear communication and expectations between both the preceptors and the student in order to create a successful rotation. Furthermore, several former students described the importance of being able to incorporate feedback from different managers into their practice as a result of their experiences in non-traditional teaching models.

\section{Discussion}

Studies in pharmacy education evaluating studentpreceptor models have primarily assessed clinical indicators. Few have described learner perceptions of their learning experience. Among those that have been published, focus has been on the implementation of one teaching model in one particular clinical area, thereby limiting generalizability of their findings. Additionally, these studies often use online surveys and journaling rather than interviews. In this study, we explored pharmacy students' experiences in three student-preceptor models (CoP, NPT, PAL) in many clinical areas using semi-structured interviews. We also analyzed learners' perceptions of how these models may have affected their knowledge, skills, attitudes, behavior, and professional practice.

Most of the literature evaluating teaching models in experiential rotations have focused on NPT. Our findings regarding perceptions are similar to what has previously been described. This model provided a supportive learning environment primarily through learners' comfort in relatability as junior learners related better to their "nearpeer" than to their preceptor because of the closeness in age and educational level. ${ }^{10,16,30}$ It also increased clinical knowledge, improved self-management skills, and provided opportunities for near-peer teaching., ${ }^{9}, 10,16,21,30$ Potential challenges included conflicting personalities and junior learners feeling intimidated by senior learners. ${ }^{10,31}$ This model is unique in that it fosters mentorship between junior and senior learners. Senior learners taught junior learners, reviewed pharmacy work-ups, discussed patient cases, and acted as role models. ${ }^{30,31}$ In our study, learners identified that this relationship, among other reasons, helped them develop their professional practice including their practice as a preceptor. For instance, one participant (now a practicing pharmacist) explains that to help the learning of their students, they model behavior because when they were a junior learner, they felt that observing a senior learner in their patient interactions, work-ups, and presentations was particularly valuable to their learning experience. To our knowledge, no other pharmacy studies have described the perceived impact this teaching model has on practice; however, this influence has been described in other professions. ${ }^{5,32}$

There is less literature describing PAL experiences; however, many of the themes overlap with those for NPT. The perceived benefits of PAL included independence, motivation, peer teaching, and an easier transition from classroom to practice. "Independence from the preceptor" has been identified as a key advantage of using this model in pharmacy and other professions as students develop self-management and teamwork skills and look to solve 


\section{American Journal of Pharmaceutical Education 2019; 83 (10) Article 7367.}

problems among themselves before asking their preceptor. ${ }^{5,8}$ As for motivation, students acknowledged a positive peer pressure existed in which they compared their progress to that of other students on the rotation. This pressure has been described in physiotherapy, occupational therapy, and medicine, and may lead to better professional development. ${ }^{33,34}$ Because of their similar knowledge base, students were able to explain complex topics using language that their peers could understand (cognitive congruence); this has also been seen with NPT. ${ }^{9,33}$ Several mentoring opportunities were identified, particularly when one student was more experienced than others and rotations overlapped..$^{5}$ This made the rotation an easier transition from the classroom to practice as students felt less pressure, and it allowed for knowledge sharing and peer learning, which is reinforced throughout the curriculum. This model influenced how participants later worked with their peers in practice, ie, they reported having a collaborative and team-focused approach to solving complex issues. The potential challenges identified (eg, competition between learners, conflicting personalities, and knowledge gap between learners) have also been described by other studies in physiotherapy and occupational therapy. ${ }^{5}$

Despite being the most common teaching model in our study, the literature describing learner perceptions of $\mathrm{CoP}$, even for other professions, is scarce. Similar to other professions, students in this model had opportunities to observe different practice styles from their preceptors, as well as to receive more attention and feedback (when compared to a one-to-one model). ${ }^{5}$ For therapeutic discussions, a preceptor with expertise and experience in a specific field could lead that discussion, which has been shown by others to increase student knowledge, confidence, and clinical decision making. ${ }^{35}$ We are the first to describe how pharmacy learners perceive this may impact their practice. Specifically, that this model helped to navigate the complexities of having multiple supervisors and improved the way they receive feedback. The challenges from CoP included adjusting to preceptors' different expectations, when communication was lacking between preceptors, and when preceptors were not aware of the learner's level of experience. ${ }^{36}$ One way to address these challenges is to maintain a log of student progress and have preceptors collaborate to establish clear expectations with students at the beginning of the rotation. Despite these challenges, students endorsed this model and highlighted its many advantages.

Overall, this study has a number of key strengths. First, our data were analyzed using Kirkpatrick's levels in order to evaluate both the learner's perceived impact on their learning and their pharmacy practice. Second, we achieved data saturation for CoP, PAL, and NPT. Third, to increase trustworthiness, four independent reviewers developed a codebook using an iterative process in order to establish consistency of interpretation, and two independent reviewers coded all transcripts to increase reliability. Last, our sample was representative of our study population as we used the purposeful sampling technique and the inclusion criteria were established to be optimally representative. Although there is no standard guideline to determine an appropriate sample size for this type of study, we felt that a $10 \%$ representative sample was appropriate, as two of the cohorts (2015 and 2016) had graduated from the school at the time the interviews were conducted.

This study has some limitations. The first is the potential for volunteer bias as learners were only included in the study if they volunteered to participate. In spite of this, this group was representative due to our inclusion criteria, sampling technique, and the variety of responses and opinions that were discussed during interviews. The second is that these findings cannot be applied to all learners and all non-traditional learning models. In particular, only one learner identified as the senior student in an NPT model; therefore, we could not reach saturation in describing these experiences. However, because of our inclusion criteria, it was unlikely that we would get many learners who had experienced a senior role as we only included final-year rotations. Additionally, there are other variations of teaching models, such as multiple students with multiple preceptors, which we did not differentiate in our study. Third, the possibility of recall bias is apparent as some learners were interviewed up to three years after their rotations. Additionally, we described only student perceptions of outcomes and we are unable to corroborate with objective measures of attainments of learning outcomes. Fourth, there was the potential for social desirability bias tendencies. ${ }^{24}$ This limitation was minimized during the interview by using hypothetical cases or reframing questions when appropriate. The fifth limitation is that in many cases, the interviewer had established relationships with the research participants. Because of this relationship, participants may have been more or less likely to participate in the study or discuss experiences during their interviews. Nevertheless, additional steps were taken to ensure trustworthiness and credibility of the data as described. In addition, as the interviewer was involved in both data collection and analysis, an unintended bias may have been introduced. However, this was mitigated through the independent coding of six transcripts by four of the authors, the development of a codebook, and consensus discussions with the larger group to identify 


\section{American Journal of Pharmaceutical Education 2019; 83 (10) Article 7367.}

categories and themes. Finally, this study describes the experience from the student's lens and does not consider the perspective of the preceptor. Future studies describing preceptors' experiences using these teaching models would fill this void.

Although this study was limited to Canadian participants from one large pharmacy school, we believe that many of the overall findings are very relevant and generalizable to other pharmacy and health profession programs globally as these teaching models can be applied in different types and sizes of institutions and health care settings. In fact, this study included data from rotations in 14 different hospital institutions that differed in their size, type, location, and specialties. To date, most of the literature on non-traditional learning models in pharmacy practice are from the United States, as Canada more recently expanded its number of required experiential education rotations with the widespread implementation of the PharmD program.

\section{Conclusion}

This study described students' experiences in nontraditional preceptor models within experiential education. As institutions look to incorporate more non-traditional models to accommodate the increase in required student rotations, these findings may provide further support in considering these teaching models. In addition, these results may provide reassurance that adopting these models in experiential practice does not appear to have negatively affected the learner experience. Indeed, these results suggest that non-traditional student-preceptor models can contribute to an enhanced approach to patient care and professional practice.

\section{ACKNOWLEDGMENTS}

Dr. Zubin Austin for his help in study design and data analysis.

\section{References}

1. Management Committee. Ottawa (ON): Moving forward: pharmacy human resources for the future. Final report. Canadian Pharmacists Association. https://www.hhrrhs.ca/index.php? option $=$ com_mtree\&task $=$ att_download\&link_id $=4506 \&$ cf_id=68\&lang=en. Published 2008. Accessed May 12, 2019.

2. Position statement and joint resolution on the Doctor of Pharmacy (PharmD) for the first professional degree at universities in Canada. Association of Faculties of Pharmacy of Canada and Association of Deans of Pharmacy of Canada. https://www.afpc.info/sites/default/ files/AFPC_ADPC_PharmD_Position_Statement_Resolution Sept_2010.pdf Published February 2010. Accessed May 12, 2019. 3. Cameron K, Fernandes O, Musing EL, Raymond C. Increasing capacity for experiential rotations for pharmacy learners: lessons learned from a multisite teaching hospital. Can J Hosp Pharm. 2016;69(1):23-29.
4. Danielson J, Craddick K, Eccles D, Kwasnik A, O'Sullivan TA. A qualitative analysis of common concerns about challenges facing pharmacy experiential education programs. Am J Pharm Educ. 2015 2015;79(1):Article 6.

5. Loewen P, Legal M, Gamble A, Shah K, Tkachuk S, Zed P. Learner: preceptor ratios for practice-based learning across health disciplines: a systematic review. Med Educ. 2017;51(2):146-157. 6. MacDonald M, Thompson A, Ton J, Mysak T. Novel models of precepting: the Alberta experience. Can J Hosp Pharm.

2016;69(1):67.

7. Topping KJ. The effectiveness of peer tutoring in further and higher education: a typology and review of the literature. Higher Educ. 1996;32(3):321-345.

8. Lindblad AJ, Howorko JM, Cashin RP, Ehlers CJ, Cox CE. Development and evaluation of a student pharmacist clinical teaching unit utilizing peer-assisted learning. Can J Hosp Pharm. 2011;64(6):446-450.

9. Leong C, Battistella M, Austin Z. Implementation of a near-peer teaching model in pharmacy education: experiences and challenges. Can J Hosp Pharm. 2012;65(5):394-398.

10. Sharif-Chan B, Tankala D, Leong C, Austin Z, Battistella M. An observational case study of near-peer teaching in medical and pharmacy experiential training. Am J Pharm Educ.

2016;80(7):Article 114.

11. Secomb J. A systematic review of peer teaching and learning in clinical education. J Clin Nurs. 2008;17(6):703-716.

12. Ten Cate O, Durning S. Peer teaching in medical education: twelve reasons to move from theory to practice. Med Teach. 2007;29(6):591-599.

13. Currens JB, Bithell CP. The 2:1 clinical placement model: perceptions of clinical educators and students. Physiotherapy. 2003;89(4):204-218.

14. Moore A, Morris J, Crouch V, Martin M. Evaluation of physiotherapy clinical educational models: comparing 1:1, 2:1 and 3:1 placements. Physiotherapy. 2003;89(8):489-501.

15. Bates JS, Buie LW, Amerine LB, et al. Expanding care through a layered learning practice model. Am J Health Syst Pharm.

2016;73(22):1869-1875.

16. Bates JS, Buie LW, Lyons K, et al. A study of layered learning in oncology. Am J Pharm Educ. 2016;80(4):Article 68.

17. Mathys M, Neyland-Turner E, Hamouie K, Kim E. Effect of pharmacy students as primary pharmacy members on inpatient interdisciplinary mental health teams. Am J Health Syst Pharm. 2015;72(8):663-667.

18. Delgado O, Kernan WP, Knoer SJ. Advancing the pharmacy practice model in a community teaching hospital by expanding student rotations. Am J Health Syst Pharm. 2014;71(21):18711876.

19. Cooper J, McCall C, Marshburn R, Burfield A. A senior care clerkship for pharmacy students. Consult Pharm.

2006;21(6):482-492.

20. Grabe DW, Bailie GR, Manley HJ, Yeaw BF. The early patientoriented care program as an educational tool and service. Am J Pharm Educ. 1998;62(3):Article 279.

21. Polo I, Triplett JW, Aceves-Blumenthal C. Integrated clinical geriatric pharmacy clerkship in long term, acute and ambulatory care. Am J Pharm Educ. 1994;58(2):165-170.

22. Skledar SJ, McKaveney TP, Ward CO, Culley CM, Ervin KC, Weber RJ. Advanced practice internship: experiential learning in a drug use and disease state management program. Am J Pharm Educ. 2006;70(3):Article 68. 


\section{American Journal of Pharmaceutical Education 2019; 83 (10) Article 7367.}

23. Sandelowski, M. Sample size in qualitative research. Res Nurs Health. 1995;18(2):179-183.

24. Boet S, Sharma S, Goldman J, Reeves S. Review article: medical education research: an overview of methods. Can J Anaesth. 2012;59(2):159-170.

25. Kirkpatrick DL. Evaluating Training Programs: The Four Levels. 3rd ed. San Francisco, CA: Berrett-Koehler; 2006.

26. Krefting L. Rigor in qualitative research: the assessment of trustworthiness. Am J Occup Ther. 1991;45(3):214-222.

27. Hsieh HF, Shannon SE. Three approaches to qualitative content analysis. Qual Health Res. 2005;15(9):1277-1288.

28. Yardley S, Dornan T. Kirkpatrick's levels and education 'evidence.' Med Educ. 2012;46(1):97-106.

29. Anderson C. Presenting and evaluating qualitative research. Am J Pharm Educ. 2010;74(8):Article 141.

30. Tsang L, Le MH, Teo V, Hardy B. Evaluation of a new hierarchical teaching model for pharmacy students in experiential education. Can J Hosp Pharm. 2013;66(3):184-189.
31. Pettit NN, Johnston S, Fuller PD, May JR, Phillips H. Managing multiple residents with incongruent personalities: A case-based scenario for the new preceptor. Am J Health Syst Pharm. 2014;71(13):1071-1072.

32. Evans DJ, Cuffe T. Near-peer teaching in anatomy: an approach for deeper learning. Anat Sci Educ. 2009;2(5):227-233.

33. Ross MT, Cameron HS. Peer assisted learning: a planning and implementation framework: AMEE Guide no. 30. Med Teach. 2007;29(6):527-545.

34. Rindflesch AB, Dunfee HJ, Cieslak KR, et al. Collaborative model of clinical education in physical and occupational therapy at the Mayo Clinic. J Allied Health. 2009;38(3):132-142.

35. McClendon KS, Malinowski SS, Pitcock JJ, et al. A multipreceptor approach to ambulatory care topic discussions. Am J Pharm Educ. 2014;78(4):Article 77.

36. Svejda M, Goldberg J, Belden M, Potempa K, Calarco M. Building the clinical bridge to advance education, research, and practice excellence. Nurs. Res. Pract. 2012(2012); 826061. 